\title{
Developmental Psychological Analysis of the Hadith of Prayers for Children
}

\author{
Acep Komarudin, Erihadiana, Teti Ratnasih, Asep Andi Rahman, A. Mujahid Rasyid \\ UIN Sunan Gunung Djati \\ Bandung, Indonesia \\ acep_akom@yahoo.com, erihadiana@uinsgd.ac.id, teti.ratnasih@uinsgd.ac.id
}

\begin{abstract}
The aim of this study is to explore the early command of prayer for children in the study of depelopment of psychological. This research is carried out by analyzing prophet tradition about the beginning of the command of prayer for the child and analyzed by using the depelopment of psychological perspective. The source of data used in this research is the books of hadis and books which are discussing about the development of children. The method used in this research is the literature in qualitative approach. The data analysis was conducted by conducting in-depth study and Forum Group Discussion (FGD) on praying command hadis toward children and the children development study. The results of this result showed that the 7 years old is the right age for early embed commands prayer for children, because in this level, and psychologically, children get in the category of pre-conventional main characteristic of compliance and penalties as well as the emergence of a personal request. Meanwhile, at the $\mathbf{1 0}$ years old where the tradition states for their punishment in the form of a blow for children who leave the prayer, because children get at this age in the category Interpersonal accord and conformity in which children are able to choose which is good and bad for him.
\end{abstract}

Keywords-hadis; psychological of development; shalat intruction

\section{INTRODUCTION}

The development of psychology and the soul of the child's religion experienced several potential stages. Both go hand in hand with the stages of child development. This potential period requires parents as the first person to come into contact with them must pay attention to changes at that stage. Since childbirth has the potential of religious fithrah, which then fithrah is functioning in the future through the process of guidance and training after being at the stage of maturity [1]

That is why Islam with its ins and outs instructs the education of children at an early age to perform prayer services. In other words, the command of the education of prayers aimed at children aged 7-10 years is very important because at that age the child's psyche is very sensitive and his memory is very strong, so that if the child is accustomed to pray, then he will be accustomed to carry out the mandate and responsibility and later the adult will always carry out the commands of religion and leave what is prohibited by the Shari'ah religion.
The problem that arises is when the command of prayer as contained in the Hadith of the Prophet is from the age of 7 years, which is not yet in the age of baligh, so they have not yet been converted. This is what the researcher will try to express using the blade of developmental psychological analysis, so that the results of this study are expected to have a scientific strengthening of the Prophet's hadith regarding the command of prayer starting from the age of 7 years.

\section{MATAN TAKHRIJ AND HADITH CONTENT}

There are a number of hadith texts and their sanad series about the obligation of parents to command their children after reaching a strategic age, which is 7 years old, to pray five times a day. The text and series will be simplified in takhrij activities (refer to the hadith to the original source) below.

Abdu Dawud (w.275/889) in (w.275/889) in the compilation of his hadith, Sunan Abi Dawud, says:

Muhammad ibn Isa, Ibn al-Tabba ', told us, Ibrahim bin Sa'd told us, from' Abd al-Malik bin al-Rabi 'bin Sabrah, from his father, from his grandfather, he said: The Prophet : "Command your child (s) to pray when you are seven years old; and if he is ten years old, beat him (for leaving the prayer) (murual-sabiyybialsalahidhabalaghasab 'sinin,waidhabalagha'ashrsininfaidribu hu'alayha)."

The above hadith is narrated:

- Abu Dawud (w.275/889) in Sunan Abi Dawud, BabalSalalah (Salat) [2].

- Al-Tirmidhi (w.279/892) in Sunan al-Tirmidhi, chap. Al-Salalah, with the editor of "allimu (learn)" as a substitute for "muru", from 'Ali bin Hujr, from Harmalah bin' Abd al- 'Aziz, from' Abd al-Malik ibn alRabi ', from al-Rabi' ibn Sabrah, from Sabrah bin Ma'bad, from the Prophet [3] (points "from 'Abd alMalik ibn al-Rabi' from al-Rabi 'ibn Sabrah, from Sabrah bin Ma'bad, from the Messenger of Allah "will be shortened" and so on ").

- Al-Darimi (w. 255/869) in Sunan al-Darimi, with editors as Tirmidhi, from the path of 'Abd Allah ibn alZubayr al-Humaydi, from Harmalah bin' Abd al-'Aziz, and so on [4] 
- Ibn al-Jarud (w. 308/920) in al-Muntaqa, chapter alShalah, with the editor as meant by the editorial editor of Abu Dawud, from the path of Muhammad bin Hisham, the son of Milas, from Harmalah bin 'Abd al'Aziz, and so on [5].

- Ibn Khuzaymah (w. 311/923) in Sahih Ibn Khuzaymah, chapter al-Shalah, with editors as the editors of alTirmidhi, from the path of 'Ali ibn Hujr,' Abd al-Jabbar bin al-'Ala 'and Ibn' Abd al -Hakim, from Harmalah bin 'Abd al-'Aziz, and so on [6].

- Al-Tahawi (w.321/933) in Sharh Mushkil al-Athar, with editors as al-Tirmidhi's editorial, from the path of Ibn 'Abd al-Hakim, from Harmalah bin' Abd al-'Aziz, and so on [7].

- (a) Al-Tabari (w. 360/971) in al-Mu'jam al-Kabir, with the editor as the editor of al-Tirmidhi, from the path of 'Amrw bin Khalid al-Harrani, Khalaf bin' Amrw al'Amiri and 'Abd Allah ibn al-Zubayr al-Humaydi, from Harmalah bin' Abd al-'Aziz, and so on [8]; (b) with the editor as meant by the editorial of Abu Dawud, from the path of Yahya al-Himmani, from Ibrahim bin Sa'd, and so on [9]; with the editor as the reaction of the Mother of God, from the path of Ibn Abi Shaybah, from Zayd bin al-Hubab, and so on [10]; (c) with the same editor, from the path of Ahmad bin 'Amrw al-Khallal, from Ya'qub bin Humayd, and so on [11].

- Al-Hakim (w. 405/1015) in al-Mustadrak, babalThaharah, with editor as al-Tirmidhi, from the path of Ibn 'Abd al-Hakim, from Harmalah bin' Abd al-'Aziz, and so on.

- (a) Al-Bayhaqi (w. 458/1066) in al-Sunan al-Kubra, Babal-Shalah, with editors as meant by the editorial of Abu Dawud, from calamity as a way of channeling [12]; (b) in Ma'rifat al-Sunan, chapter al-Shalah [13]; (c) with the editor as the editor of al-Tirmidhi, from the path of Ibn 'Abd al-Hakim, from Harmalah bin' Abd al'Aziz, and so on [14].

- (d) in al-Sunan al-Saghir, with the same editor and path [15].

- Al-Baghawi (w. 516 A) in Sharh al-Sunnah, chap. AlSalalah, with the editorial as Abu Dawud's editorial meaning, from the path as Ibnal-Jarud's line [16].

The hadith above has shahid (supporter, ie more than one friend narrates the hadith from the Messenger of Allah). Abu Dawud (d.275/889) says:

Mu'ammal bin Hishamyakni al-Yashkuri told us (haddathana), Isma'il told us, from ('an) Sawwar bin Abi Hamzah, Abu Dawud said: He was Sawwar bin Dawud Abu Hamzah al-Muzanni al-Sayrufi, from 'Amrw bin Shu'ayb, from his father, from his grandfather, he said: The Messenger of Allah said: "Command your children to pray at the age of seven, and beat them (for leaving prayer) at the age of ten, and separate their beds (at the age of ten) (muru awladakum bi al-Salah wa hum, 'sab' sinin, wa idribuhum 'alayha, wa hum abna' 'ashr, wa farriqu baynahum fi almadaji'). "

The above hadith is narrated:

- Abu Dawud (w. 275/889) in Sunan Abi Dawud, chapter al-Shalah (prayer) [17]; and with the editor as the editorial meaning of al-Khara'itidi below, from the path of Zuhayr bin Harb, from Waki 'bin al-Jarrah, from Sawwar bin Dawud, from' Amrw ibn Shu'ayb, from Shu'ayb bin 'Abd Allah, from 'Abd Allah bin' Amrw bin al-'As, from the Messenger of Allah (point "from Sawwar bin Dawud, from 'Amrw bin Shu'ayb, from Shu'ayb bin' Abd Allah, from 'Abd Allah bin' Amrw bin al-' As, from the Messenger of Allah "will be abbreviated" and so on ").

- Ibn Abi Shaybah (w. 235/850) in Musannaf Ibn Abi Shaybah, chapter al-Shalawat, with editors as meant by the editorial of Abu Dawud, from the path of Waki 'bin al-Jarrah, and so on [18].

- (a) Ibn Hanbal (w. 241/855) in Musnad Ahmad, the chapter Musnad 'Abd Allah ibn' Amrw ibn al-'As, with the editor as the editorial meaning of Abu Dawud, from the path as Ibn Abi Shaybah [19]; and (b) with the editor as the editorial meaning of al-Khara'itidi below, from the path of Muhammad bin 'Abd al-Rahman alTufari, from' Abd Allah ibn Bakr al-Sahmi, and so on [20].

- Al-Dullabi (w. 310/923) in al-Kuna wa al-Asma ', chapter man kunyatuhu Abu Hamzah (the person nicknamed Abu Hamzah), with the editor as meant by the editorial of Abu Dawud, from the path of Ziyad bin Ayyub, from Waki' bin al-Jarrah, and so on [21].

- Al-'Uqayli (w. 322/934) in al-Du'afa 'al-Kabir, with editors as meant by the editorial editor of Abu Dawud, from the path of Ya'qub bin al-Jarrah al-Khuwarizmi, from Mughirah bin Musa, and so on [22].

- Al-Khara'iti (w. 327/939) in Makarim al-Akhlaq, chapter ma yustahabbu li al-mar 'li sitr fakhidhihi idha kanat min' awratihi (closing one's thighs because they include genitalia), with editors as meant by the editorial of Abu Dawud, with the addition "wa idha zawwaja alrajul very know aw ajirahu, fa la yara ma bayna surratihi wa rukbatihi, fa innahu min 'awrah (and if a man wants to marry his sahayan servant, then he is forbidden to see [limbs] between his navel and knee for it is aurat, "from the path of 'Abd Allah ibn al-Hasan alHashimi, from' Abd Allah ibn Bakr al-Sahmi, and eternally [23].

- (a) Al-Daraqutni (w. 385/995) in Sunan al-Daraqutni, chapter al-Shalah, with the editor as meant by the editorial of al-Khara'iti, from the path of Ahmad bin Mansur Zaj, from al-Nadr bin Shumayl, and so on [24]; and (b) from the path of Muhammad ibn Habib alShilmani, from 'Abd Allah ibn Bakr, and afterwards [25]. 
- Al-Hakim (w.405/1015) in al-Mustadrak, chapter alThaharah (purifying), with the editor as meant by the editorial editor of Abu Dawud, from the path of Sahl bin Mihran, from 'Abd Allah ibn Bakr, and so on [26].

- Abu Nu'aym al-Asbahani (w. 430/1038) in Haliyat alAwliya ', with the editor as the editorial meaning of alKhara'iti, from the path of Ahmad bin Abi al-Hawari, from Waki' bin al-Jarrah, and so on [27].

- (a) Al-Bayhaqi (w. 458/1066) in al-Sunan al-Kubra, sub-section 'Awrat al-Rajul, with editors as meant by the editorial of al-Khara'iti, from the path as the second al-Daraqutni line [28 ]; (b) from the path as the first alDaraqutni line [29]; (c) from the path as in the path of al-'Uqayli [30]; (d) with the editor as Abu Dawud's editorial meaning, from the path as jalural-Hakim [31]; (e) in Shu'ab al-Iman, with editors and paths as editors and al-Hakim path [32].

- Al-Khatib al-Baghdadi (w. 463/1072) in the Baghdad Date, with editors as meant by al-Khara'iti editors, from the path as the second al-Daraqutni line [33]

- Al-Baghawi (w. 516 H) in Sharh al-Sunnah, babalShalah [34].

The essence of dynamic potential in every human being lies in faith or belief, science, morality and practice. So that in the Islamic strategy, these four essential dynamic potentials become the focal point of the circle of the process of Islamic education to the achievement of the ultimate goal of education, that is, believers or Muslims, muhsin or mukhlisin muttaqin.

Religious exercises that involve worship such as prayer, prayer, reading the Qur'an, praying in congregation must be familiarized since childhood, so that over time will grow a sense of pleasure in doing the worship. This is why the education of prayer is ordered at the age of 7 years and 10 years if it does not carry out the worship, then the religion commands hitting.

The above hadith had a statement from the Messenger of Allah, which gives us an idea of when to start the education of children especially the command to pray. In the above hadith, it is clearly conveyed by the Messenger of Allah that the child must be instructed to perform prayers starting at the age of 7 years and when he is 10 years old, and the child still does not pray then it is obligatory for him to be given a punishment.

\section{EMOTION DEVELOPMENT IN CHILDREN AGES 7-12 YEARS}

\section{A. Parent's View}

\section{1) Disobedient Period}

Lebel given in the final period in childhood is difficult. Now children follow their peers or social groups more. The child is less responsible for home affairs and he prefers his friend's business.

\section{2) Fighthing Period}

At this time, children always fight with other family members or their peers, especially when the child feels a home atmosphere that is unpleasant, disciplined, weak or authoritarian, then the child will always make the atmosphere noisy, noisy, troublesome and can lead to fights between groups.

\section{3) Teacher's View}

Educators give children's label as the end of elementary school. Now the child is expected to be able to follow the basic knowledge he has received during preschool. Now the child is always motivated, achieving and forming new habits in achieving success. If the habits have a good impact, this will be brought to adulthood. If a bad impact will cause new problems [35]

\section{B. Psycholgist's View}

\section{1) Playing Period}

The end of childhood is called playing time at this age, children begin to form new games in schools and play groups, usually at this age children feel happy if they are able to play in groups and are accepted by the group and in this condition the child always follows the standard rules the group is like a dress appearance or speech.

\section{2) Creativity Period}

The end of childhood is also called a period of creativity because at this time the creativity of a child is very high and always motivated to show creativity like painting and if a child cannot show his creativity, he will often be ridiculed, criticized, ridiculed, insulted, stupid and not creative.

From some of the above views can be concluded that psychologically a child at this age is the age in which the child began to look for his teak began to interact with his age group is also a period in which he needs more attention than others, especially his parents. And at this age is a period of emotional uplift but, the heightening of these emotions is sometimes caused by physical or environmental conditions as well as when a child is sick or tired tends to be angry, fussy, and generally difficult to deal with

The emotional characteristics of children are as follows:

- Child's emotion lasts relatively shorter (briefly),

- Child's emotions are strong or great.

- Child's emotions are volatile.

- Child's emotions appear repeatedly.

- The emotional response of children varies.

- Child's emotions can be detected or detected by symptoms of behavior.

- Child's emotions experience changes in strength.

- Changes in emotional expressions

\section{Social DEVElopment In CHILDREN Ages 7-12 YeARS}

At this time it is often referred to as the age of the group because it is characterized by an interest in friends' activities and an increased strong desire to be accepted as a group member. The group is called a gang of children. According to psychologists there are four differences between child gangs 
and teen gangs, the first is to get the pleasure of their gang, especially the play group. Secondly, the children's gang consists of children who are popular with their peers. Third, children's gangs rarely have both types of gender [36]. Fourth, the children's gang consists of children of the same age and the same level of development, and who share the same interests and abilities [37].

Social interaction that occurs in children aged 7-12 is something that happens like an adult, but what distinguishes this age is how to interact. In social psychology there are several factors that we need to know in the ongoing social interaction namely;

- Imitation factor.

- Suggestion factor

- Identification factor

- Sympathy factor

\section{DEVELOPMENT OF CHILDREN INTELLIGENCE IN AGE 7-12 YEARS}

A very prominent development is the development of the mind, especially intelligence. The development of intelligence occurs very quickly. Children have begun to understand abstract things. His intelligence to fantasize is huge. Children love to hear stories, stories or stories told by parents and teachers.

At the age of 8-9 years, the ability to read in children has begun to appear. If parents and teachers can provide reading material that is appropriate for the child's mental development and supports faith, it is certainly very useful. The story of the story that children like at this age is a story that suits their situation, such as the story of a child who is the same age as him. They like to hear or read stories about animals that have been seen, beautiful natural scenery that fascinates.

At the age of 10-12 years the development of children's intelligence runs fast, so the ability to understand abstract things is increasing; and at the age of 12 children are only able to understand abstract things. Simple explanations of faith can already be given to children of this age in accordance with the development of intelligence [38].

\section{DEVELOPMENT OF CHILDREN'S RELIGION IN AGES 7-12 YEARS}

In general, children aged 7-12 are more active as described in previous explorers. Regarding child development about religion is a very special thing, from education about religion to God.

\section{1) Development of Children's Knowledge of God's Existence}

Children's beliefs grow through the exercises and upbringing received in their environment, usually trust is based on real conceptions, for example the way of thinking about god, angels, heaven, hell, genie, and so on is in the form of images he sees. This will change after everyday diving and golden opportunities so that his knowledge will grow.
Before reaching the age of seven, a child's feelings are basically negative, which is fear of opposing and trying to accept about the greatness and glory of God and to make it easier for children to accept thoughts about God (positive thinking) it is very important to put forward or explain the good deeds of God., which encourages the child to feel secure.

As a consequence of positive feelings towards God, belief in God is not just a belief and hypothesis of the mind, but an emotional attitude that is closer to the needs of the soul. The needs of the child's soul rather than the definition of society and the thought of God is the satisfaction of the child's need for a protector

From the age of seven to eight years a child's relationship with God is an individual relationship because of the emotional connection between him and an invisible thing imagined by his own way. The beliefs about and the environment taught at this age have not become part of his mind except at a later age. This depends on the influence of education and automatic exercises of the environment on the growth of the child's soul is not much, but the most important is the interaction between children with the existing belief environment.

\section{2) The Importance of Child's Relations with Parents}

Because parents are central to the child's spiritual life and as a result of being acquainted with the outside world, every child's emotional reaction to his thought is later influenced by his attitude from the beginning of his life.

\section{3) Birth and Death}

The child's understanding of the problem of death can bring a new principle that is the principle of morality, this leads to a new attitude that looks at the marks in various sides, as well as to God, if the child returns to God whatever happens this happens because first thought that everything happened because his will, then because his father later and ultimately because of the will of God. This thought has not yet covered the law of causality due to illogical reasons or personal will for no reason.

However, after the child is busy with an outside child and sees events that are not dependent on his will then other reasons are sought from this world too, then after not finding the answer or cause and consequence he returns to God. The more logical understanding of the children, the later they will return to God as the cause. It is as if the child's thought happened to the child logically and that thought is advanced. And if a child who is seven years old is busy signifying how he was born or created about the first human being means that he is progressing because he no longer thinks about the events of himself or someone else, even the occurrence of a human being, if the child has reached this level in his mind then this means that the event and birth can no longer answer the problem of human events, in this case can not be resolved except by God [39].

\section{RESEARCH METHODOLOGY}

This study uses the method of the study of hadith analysis about the command of prayer for children at the age of 7-10 years, the analytical tool in this study is developmental psychology, especially cognitive development theory that 
examines the understanding of the ability of understanding children aged 7-10 years. Data sources are taken from the books of hadith related to research topics, as well as theories of developmental psychology.

\section{VIII.RESULTS AND DISCUSSION}

Before moving further in breaking down the meaning of the hadith "muru al-sabiyy", it is better to emphasize the substance of the hadith "the burden of the law is lifted from three people (rufi'a al-qalam 'an thalathah)," one of which is "from children until they reach baligh (wa min al-sabiyy hatta yahtalima). "Ages 7 to 10 years are generally not a period of baligh (except in certain cases), and the context of this"muru al-sabiyy" hadith is indeed a child which has not yet reached the baligh period. It is important to stress the views that rigidly require prayers in children aged 10 years and over despite not reaching baligh. Al-San'ani (d. 1182/1768), for example, stated, the command to "beat" a child at the age of 10 years if he leaves prayer indicates that a 10-year-old child has been burdened with the law (mukallaf) prayer. Whether based on textual or contextual understanding, views al-San'ani which still does not need to be taken into account.

In the sharia literature (a kind of interpretation in the context of the Quran) hadith, from the most classic to the most modern, generally sharih (a kind of exegete in the context of the Quran) still interpret textual "blows". In addition, sharih are also lacking, not even at all, exposing early childhood worship education contained in the hadith "muru al-sabiyy." AlKhattabi (d. 388/998) for example concluding, sentence "if it has arrived ten years, then beat him for leaving prayer "shows the more assertive sanction if the one who leaves the prayer is a baligh [40]. Al-Khattabi then explained the law of the Covenant of al-Shalah (the person who left prayer intentionally) in a rather detailed manner [41]. It is unfortunate if the most important element in this hadith, namely the education of child worship, just escapes from the explanation of al-Khattabi.

The exposition of the education of children's prayers in certain portions is seen in the descriptions of the next sharih. Badr al-Din al-'Ayni (d. 855/1451), also al-Tibi [42] and Ibn Hajar al-'Asqalani (d. 773/1448), describes, the verb the command "muru" (command) is not show obligation (wujub) prayer for children, but only just learning (irshad) and education (ta'dib) which is charged to the parents or the guardian. Because the child discussed here has not reached Baligh, so he is not a mukallaf. According to al-'Ayni (also al'Azim al-Abadi) (w.st. 1310/1892) [43]. the age of 7 years is chosen explicitly as the beginning of the teaching and education of children's prayer, because at that time the child has reached black (can distinguish good and bad). While the age of 10 years was chosen explicitly as the beginning of the application of "blows" because at that time the child was already an inch to the high school, that is, at least 12 years of age. But the point is, according to al-'Ayni, all this is only learning and education of the child's prayer [44]. That is, this "muru al-sabiyy" hadith actually does not want to explain the law of prayer for children who have not reached baligh.
Long before al-'Ayni and Ibn Hajar, Qawam al-Sunnah (d. 535/1141) considered education and the teaching of prayers accompanied by "blows" before baligh as a process of habituation so as not to feel heavy working on prayer in baligh [45]. Furthermore, in line with Qawam al-Sunnah, Ibn 'Allan (w. 1057/1647), also al-'Iraqi (w. 806/1404) [46] and al-Mala' Ali al-Qari (w. 1014/1606 ), the command to pray to the child at the age of 7 years and the command to beat him at the age of 10 years if leaving prayer is just to practice and habituation, so that the child will never leave the prayer when he has been prayed [47].

Explanation of the "beat" to 10-year-old who are reluctant to pray is from Muhammad ibn 'Abd al-Rahman al-'Alqami (w. 969/1561). Al-Alqami concluded, the meaning of the word "alshalah" is learning the procedure of prayer, both terms and conditions, to children; and after that just instruct the child to pray [48]. Al-'Alqami explicitly warns, what is meant by "punch" (darb) here is a blow that is not painful, even hurt. He also cautioned, the "blow" should not be addressed to the face [49]. However, no matter al-'Alqami softens the meaning of "beating", he still understands it textuall.

In line with al-'Alqami, Muhammad bin Salih al-'Uthaymin (1928-2001M) explained, the purpose of "blows" here is the usual blow that produces education without the slightest element of harm. Al-'Uthaymin also underlined, the Messenger of Allah ordered the beating of children solely to educate them, and not at all to harm them [50]. Furthermore, based on this "muru al-sabiyy" hadith, Al-'Uthaymin commented on the thinking of modern educators who were reluctant to apply "physical violence" in any forms in schools. According to him, this kind of thinking is wrong, because generally children do not work if they are only reminded by words; "Ordinary blows that educate without hurting," he said, were far more effective and efficient for them [51, 52]. Whatever and however the response of modern educators in schools to al-'Uthaymin's criticism, which is clear both they and al-'Uthaymin, both highlight the elements of education (and that is what matters; it's just possible in a way that varies from one another).

From the explanations of the sharih above, at least according to personal writers, there are fundamental deficiencies which unfortunately actually become the most important messages that the Prophet intended through the hadith "muru al-sabiyy." These important points may be simplified as follows; first, the exposition of child worship education in general is not only limited to prayer services, although textually it is only listed in the hadith; second, a comprehensive psychological explanation of the choice of 7 years of age as the beginning of religious practice, and 10 years as the beginning of the application of punishment; once again, the explanation must be more psychological, than purely theological; third, reinterpretation of the meaning of "beating" (darb): is the beating a goal, or is it just a medium / means of education?

Prayer itself is not the main goal in the education of children's prayers in mosques, as "fasting" and the Hajj itself in the tradition of poso mbeduk education and the practice of rituals of Hajj in schools, are also not the main objectives. The main purpose is none other than the education of habituation of 
children towards the services that later must become the practice of their lives. With habituation education, the child's worship, as explicitly stated by Qawam al-Sunnah (w. 535/1141), al-'Iraqi (w. 806/1404), al-Mala'Alial-Qari (w.1014 / 1606) and Ibn 'Allan (w. 1057/1647) above, the practice of worship is expected to be able to deepen themselves because they are accustomed to doing it early.

The command to pray for children whose essence is education, teaching and guidance on "prayer" for children, at the age of 7 years, is very appropriate. Developmental psychology describes cognition, social aspects and the development of children's religiosity in the most appropriate condition of the human soul. He as a human figure who began to build social interaction with the environment, he also as a human figure who has the fastest cognitive development between his age, and he was very happy with new things that are in accordance with the development of his soul.

Education, teaching and guidance will form a new value in the child, namely the value of readiness. Readiness in the meaning of knowing, understanding, and accepting to run everything that he knows and understands as a product of teaching. The child who gets upbringing and teaching about salat at the age of 7 will be sure to be ready to perform and establish the prayer at the time that has been established legal obligations on him. As a form of evaluation of this prayer education process, then at the age of 10 , if still not receive and perform the prayers then "beat" them. This is a punishman whose form aimed at the child to understand the importance of prayer for him. The Punishman will also form a child's value of God's "conviction", because the teaching he receives by those who leave Allah's prayer will reward him with hell. In psychology studies, the development of 10 years of age is that children in the development of their humanity, have been able to choose what is good and what is bad, including the consequences of good and bad deeds.

Again, however, the age of 7 and 10 in the hadith "muru alsabiyy" does not mean to limit the beginning of education and the beginning of the "beat" application; education must start as early as possible. It's just that the children's education in gradually and systematically should be really applied and observed from the age of 7 years as directed by Rasulullah.

The relevant concept of al-Qaradawi to understand the word "beat" in the hadith "muru al-sabiyy" furthermore is "to distinguish between the medium of change and the ultimate purpose of hadith." [53] First, we must identify the ultimate goal of "beating" in this hadith, which is nothing but strict education. In this hadith, the media / means of achieving a firm education which is the ultimate goal is by "beating", which may (again) be relevant practice at that time. So "beating" is just a medium / means that its relevance can change along with the times. If the ultimate goal, strict education, can be achieved with relevant and educational media / tools other than "beating" that today can easily be mistaken for "physical violence," then there is no problem. Thus, it is not a matter of educating children's worship firmly at the age of 10 and up by applying punishment other than "beating", such as punishment with no pocket money, punishment by cleaning the house, or whatever and however that can make the detective leave the prayer.

\section{CONCLUSION}

Child education is a process that adults do in guiding, directing and training so that children have the readiness to live in the face of challenges and problems of life called maturity. Maturity is the sense that children are able to think and act in accordance with the principles of truth, both religious and ethical ones. One form of maturity for a Muslim is able to establish prayers well without having to be ordered by anyone except for belief in Allah SWT.

Salah (prayer) education is given to children from the age of 7 years, as the hadith of the Prophet. The Hadith is actually preceded by the word "murru" which means "command". The word "command" is in fact the meaning of educate, guide it, teach the children about prayer, because the age of 7 years has not entered the adult category (baligh). The developmental psychology study of the 7-year-old child is very potential to get upbringing, guidance and teaching, because they are cognitionally in the golden period of development so fast. Socially they begin to build social interactions with their environment which makes it easier for parents to teach and sample them. It is also confirmed by the continuation of the hadith which says "Wadribuuhum" to beat the child who left the prayer at the age of 10 years. In the method of learning we are familiar with the reward and punishman method, when the child has received education and guidance but the child has not established prayer then punishment is an important method to do. The word "beat" is not in conflict with modern learning methods. In fact, the word describes the extraordinary importance of "praying" for him. The cultivation of the value of faith and readiness is the main target of the message of the hadith.

\section{REFERENCES}

[1] Z. Darajat, Ilmu Jiwa Agama, PT Bulan Bintang: Jakarta, Indonesia 1970, pp. 35-46.

[2] Abu Dawud Sulayman bin al-Ash'ath al-Sijistani, Sunan Abi Dawud, vol. 1, 494 (Beirut: al-Maktabah al-'Asriyyah, t.th).

[3] Muhammad bin 'Isa al-Tirmidzi, Sunan al-Tirmidzi, vol. 2, no. 407 (Mesir: Sharikat wa Maktabat wa Matba'at Mustafa al-Babi al-Halabi, 1975).

[4] Abd Allah bin 'Abd al-Rahman al-Darimi, Sunan al-Darimi, vol. 2, no. 1471 (Arab Saudi: Dar al-Mughni, 2000).

[5] Abd Allah bin 'Ali bin al-Jarud, al-Muntaqa min al-Sunan alMusannadah, no. 147 (Beirut: Mu'assasat al-Kitab al-Thaqafiyyah, 1988).

[6] Muhammad bin Ishaq bin Khuzaymah, Sahih Ibn Khuzaymah, vol. 2, no. 1002 (Beirut: al-Maktab al-Islami, t.th).

[7] Ahmad bin Muhammad al-Tahawi, Sharh Mushkil al-Athar, vol. 6, no. 2565 (Beirut: Mu'assasat al-Risalah, 1994).

[8] Sulayman bin Ahmad al-Tabari, al-Mu'jam al-Kabir, vol. 7, no. 6546 (Kairo: Maktabat Ibn Taymiyah, 1994).

[9] Ibid., vol. 7, no. 6547.

[10] Ibid., vol. 7, no. 6549.

[11] Abu 'Abd Allah Muhammad bin 'Abd Allah al-Hakim, al-Mustadrak 'ala al- Sahihayn, vol. 1, no. 948 (Beirut: Dar al-Kutub al-'Ilmiyyah, 1990).

[12] Ahmad bin al-Husayn al-Bayhaqi, al-Sunan al-Kubra, vol. 2, no. 2253 (Beirut:Dar al-Kutub al-'Ilmiyyah, 2003).

[13] Ahmad bin al-Husayn al-Bayhaqi, Ma'rifat al-Sunan wa al-Athar, vol. 4, no. 5722 (Karachi, Damaskus, dan Mansurah dan Kairo: Jami'at al- 
Dirasah al- Islamiyyah, Dar Qutaybah, dan Dar al-Wa'y dan Dar alWafa', 1991).

[14] Ibid., vol. 3, no. 5091.

[15] Ahmad bin al-Husayn al-Bayhaqi, al-Sunan al-Saghir, vol. 1, no. 556 (Karachi: Jami'at al- Dirasat al-Islamiyyah, 1989).

[16] Al-Husayn bin Mas'ud al-Baghawi, Sharh al-Sunnah, vol. 2, no. 503 (Damaskus dan Beirut: al-Maktab al-Islami, 1983).

[17] Abu Dawud, Sunan Abi Dawud, vol. 1, no. 495.

[18] Abu Bakr bin Abi Shaybah, Musannaf Ibn Abi Shaybah, vol. 1, no. 3482 (Riyad: Maktabat al-Rushd, $1409 \mathrm{H}$ ).

[19] Ahmad bin 'Abd Allah bin Hanbal, Musnad Ahmad, vol. 11, no. 6689 (Beirut: Mu'assasat al-Risalah, 2001).

[20] Ibn Hanbal, Musnad, vol. 11, no. 6756.

[21] Muhammad bin Ahmad al-Dullabi, al-Kuna wa al-Asma', vol. 2, no. 892 (Beirut: Dar Ibn Hazm, 2000).

[22] Muhammad bin 'Amrw al-'Uqayli, al-Du'afa' al-Kabir, vol. (Beirut: Dar al- Maktabah al- 'Ilmiyyah, 1984), 176.

[23] Muhammad bin Ja'far al-Khara'iti, Makarim al-Akhlaq wa Ma'aliha wa Mahmud Tara'iqiha, no. 457 (Kairo: Dar al-Afaq al-'Arabiyyah, 1999).

[24] Abu al-Hasan 'Ali bin 'Umar al-Daraqutni, Sunan al-Daraqutni, vol. 1, no. 887 (Beirut: Mu'assasat al-Risalah, 2004).

[25] Ibid., vol. 1, no. 888.

[26] Al-Hakim, al-Mustadrak, vol. 1, no. 708.

[27] Abu Nu'aym Ahmad bin 'Abd Allah al-Asbahani, Haliyat al-Awliya' wa Tabaqat al-Asfiya', vol. 10 (Mesir: al-Sa'adah, 1974), 26.

[28] Al-Bayhaqi, al-Sunan al-Kubra, vol. 2, no. 3233.

[29] Ibid., vol. 2, no. 3234.

[30] Ibid., vol. 2, no. 3235 .

[31] Ibid., vol. 3, no. 5092.

[32] Ahmad bin al-Husayn al-Bayhaqi, Shu'ab al-Iman, vol. 11, no. 8283 (India: Maktabat al- Rushd, 2003).

[33] Al-Khatib Ahmad bin 'Ali al- Baghdadi, Tarikh Baghdad wa Dhuyulihi, vol. 2 (Beirut: Dar al-Kutub al-'Ilmiyyah, 1417 H), 277.

[34] Al-Baghawi, Sharh al-Sunnah, vol. 2, no. 505.

[35] Herri Zan Pieter dan Namora Lumonggah penganta psikologi kebidanan. Jakarta: kencana 2010, h. 128
[36] Elizabeth B Hurlock, Psikologi perkembangan, PT Gelora Aksara Pratama, cet ke 5,1966 h. 148

[37] Robet a. Baron \& donn byrne "psikolog sosial jilid 2 edisi kesepuluh" penertbit erlangga, 2005, h. 9

[38] http://www.badkokraton.org/2009/12/ perkembangan-anak-usia-tpa-712-tahun.html

[39] Zakiah Darajat, Ilmu Jiwa Agama, PT Bulan Bintang:Jakarta, Indonesia 1970. H 35-46

[40] Hamd bin Muhammad al-Khattabi, Ma'alim al-Sunan: Sharh al-Sunan Abi Dawud, vol. 1 (Halab: al-Matba'ah al-'Ilmiyyah, 1932), 149.

[41] Ibid., vol. 1, 149-150.

[42] Abd al-Rahman bin Ahmad bin Rajab al-Hanbalai, Fath al-Bari: Sharh Shahih al-Bukhari, vol. 8 (Madinah: Maktabat al-Ghuraba' alAthariyyah, 1996), 21.

[43] Muhammad Ashraf bin Amir al-'Azim al-Abadi, 'Awn al-Ma'bud: Sharh Sunan Abi Dawud, vol. 2 (Beirut: Dar al-Kutub al-'Ilmiyyah, $1415 \mathrm{H}), 115$.

[44] Lihat Badr al-Din Mahmud bin Ahmad al-'Ayni, Sharh Sunan Abi Dawud, vol. 2 (Riyad: Maktabat al-Rushd, 1999), 414.

[45] Isma‘il bin Muhammad (Qawam al-Sunnah), al-Targhib wa al-Tarhib, vol. 1 (Kairo: Dar al-Hadith, 1993), 356.

[46] Abd al-Rahman bin al-Husayn al-'Iraqi, Tarh al-Tathrib fi Sharh alTaqrib, vol. 7 (Mesir: al-Tab'ah al-Misriyyah al-Qadimah, t.th), 87

[47] Ali bin Muhammad al-Qari, Mirqat al-Mafatih: Sharh Mishkat alMasabih, vol. 2 (Beirut: Dar al-Fikr, 2002), 512.

[48] Muhammad bin 'Ali bin Muhammad bin 'Allan, Dalil al-Falihin li Turuq Riyad al-Salihin, vol. 3 (Beirut: Dar al-Ma'rifah, 2004), 134.

[49] Al-Abadi, 'Awn al-Ma'bud, vol. 2, 114. Lihat juga Muhammad 'Abd alRahman al -Mubarakfuri, Tuhfat al-Ahwadhi bi Sharh Jami' alTirmidhi, vol. 2 (Beirut: Dar al-Kutub al-'Ilmiyyah, t.th), 370.

[50] Ibid.

[51] Muhammad bin Salih al-'Uthaymin, Sharh Riyadh al-Shalihin, vol. 3 (Riyadh: Dar al-Wathan, 1426 H), 174.

[52] Ibid.

[53] Lihat Yusuf al-Qaradawi, Kayfa Nata'amalu ma'a al-Sunnah alNabawiyyah (Kairo: Dar al-Shuruq, 2006), 145-158. 